\title{
Association of Haemophilia with Down Syndrome
}

\author{
Narang GS ${ }^{1}$, Singh $\mathrm{T}^{2}$, Sharma $\mathrm{A}^{3}$, Makik $\mathrm{S}^{4}$, Kaur $\mathrm{A}^{5}$
}

${ }^{1}$ Dr. Gursharan Singh Narang, Professor, ${ }^{2} \mathrm{Dr}$. Tarsem Singh, Assistant Professor, ${ }^{3} \mathrm{Dr}$. Anubha Sharma, Senior Resident, ${ }^{4} \mathrm{Dr}$. Supriya Malik, Senior Resident, ${ }^{5}$ Amandeep Kaur, Resident. All fron the department of Paediatrics, Sri Guru Ram Das Institute of Medical Sciences and Research, Vallah, Amritsar.

\section{Address for correspondence: \\ Dr. Gursharan Singh Narang \\ E-mail: gsnarang321@gmail.com}

\section{How to cite}

Narang GS, Singh T, Sharma A, Makik S, Kaur A. Association of Haemophilia with Down Syndrome. J Nepal Paediatr Soc 2016;36(1):75-77.

doi: http://dx.doi.org/10.3126/jnps.v36i1.11949

This work is licensed under a Creative Commons Attribution 3.0 License.

\begin{abstract}
Hemophilia $B$ is a hereditary bleeding disorder caused by a lack of blood clotting factor IX. Without enough factor IX, the blood cannot clot properly to control bleeding. Hemophilia B presenting in association with Down's syndrome is quite rare. We report a case of a one month old child who presented to us with continuous unexplained bleeding.
\end{abstract}

Key words: Hemophilia B, Down's syndrome

\section{Introduction}

$\mathrm{H}^{\mathrm{e}}$ emophilia $B$ is an inherited $X$-linked recessive trait with the defective gene located on the $X$ chromosome ${ }^{1}$. Haemophilia $B$ is an inherited bleeding disorder associated with a deficiency of coagulation factor IX. The hallmark of this disease is recurrent and spontaneous bleeding into joints, which can lead to joint deformity and arthritis at an early age ${ }^{2}$.

\section{The Case}

We present a case of one month old male baby, who presented to us with bleeding from the left thigh after an intramuscular injection at that site one day back. There was history of bleeding from umbilical stump and swelling on right eye on day 13 of life. There were no noted complications during pregnancy and he was delivered in full term. At birth it was noted that the patient presented characteristics of Down's syndrome. On examination the baby was active. Features suggestive of Down syndrome were microcephaly with flat occiput, sutural diastasis, patent posterior fontanella, Mongolion slant. On systemic examination a grade \| systolic murmur was heard over tricuspid area, which was non radiating.

Investigations revealed $\mathrm{Hb}-8.9 \mathrm{gm} \%$, TLC- 9700, Platelet count 3,70,000 per cumm and PBF revealed a microcytic and hypochromic picture. Thyroid profile was normal. Activated Partial Thromboplastin time (APTT) was $>160$ sec (Ref range-22.77-31.10). Factor IX level was deranged i.e 2.40 (Ref range-70.00-120.00). Ultrasound abdomen was normal. Karyotyping was suggestive of Down syndrome. Patient was managed by transfusing Fresh frozen plasma and Factor IX concentrates. 
Table 1: Showing reference values of factor IX

\begin{tabular}{cccc}
\hline Reference level & \multicolumn{1}{c}{ Range } & \multicolumn{1}{c}{ Cases } \\
\hline \multirow{3}{*}{$5 \mu \mathrm{g} / \mathrm{mL}$} & Half to twice that level & Normal & \\
\cline { 2 - 4 } & With levels of $6-30 \%$ & Mild disease & $6-30 \%$ of cases \\
\cline { 2 - 4 } & With levels of $1-5 \%$ & Moderate disease & $30 \%$ of cases \\
\cline { 2 - 4 } & With levels of below $1 \%$ & Severe disease & $50 \%$ of cases \\
\hline
\end{tabular}

\section{Discussion}

Hemophilia $B$ is an inherited $X$-linked recessive trait with the defective gene located on the $X$ chromosome $^{1}$. Males have only one $X$ chromosome. If the factor IX gene is missing on a boy's $\mathrm{X}$ chromosome, he will present as Haemophilia B, so most people with haemophilia $B$ are males ${ }^{2}$. Estimated incidence of Haemophilia B is 1 per 30,000 male births ${ }^{3}$. Haemophilia $A$ is more common constituting 70 per cent case burden ${ }^{2,3}$. The reference level of factor IX is $5 \mu \mathrm{g} / \mathrm{mL}$ but the 'normal' range is from half to twice that level ${ }^{4}$.

Haemophilia B is characterized by deficiency in factor IX clotting activity that results in prolonged oozing after injuries, tooth extractions, or surgery and delayed or recurrent bleeding prior to complete wound healing. The age of diagnosis and frequency of bleeding episodes are related to the level of factor IX clotting activity ${ }^{4}$. Individuals with severe haemophilia $B$ are usually diagnosed during the first two years of life but its diagnosis in the first month of life has been rarely reported earlier ${ }^{4}$. Patients with severe disease experience symptoms from infancy onwards, with spontaneous haemorrhages and haemarthrosis. They may even start from the trauma of delivery, especially if instrumental. Patients with moderate disease suffer haemorrhage from minor trauma or surgery and sometimes spontaneous haemarthrosis. Haemarthrosis, transfusion related infections such as HIV and HCV, development of inhibitors are the complications ${ }^{5}$.

Down's syndrome is a major cause of mental retardation and congenital heart disease. Besides a characteristic set of facial and physical features, Down's syndrome is associated with congenital anomalies of the gastrointestinal tract, leukaemia, immune system defects, and an Alzheimer-like dementia. The association of haemophilia with Down's syndrome is rare. The baby in our case was kept in NICU, transfused FFP and pressure bandage over the affected area was applied. The association of Haemophilia with Down's syndrome is not commonly reported. We plan to closely follow up the patient. To our knowledge, this is the second case in the available literature, describing the association of haemophilia A and Down's syndrome.

\section{Conclusion}

This case highlights the importance of keeping in mind the possibility of Haemophilia while dealing with a patient of Down's syndrome with history of bleeding.

\section{References}

1. Ragni MV. Hemorrhagic disorders: coagulation factor deficiencies. In: Goldman L, Schafer Al, eds. Cecil Medicine. 24th ed. Philadelphia, Pa: Saunders Elsevier; 2011: chap 167.

2. Paul Giangrande Haemophilia B: Christmas disease. Expert Opin Pharmacother 2005;6(9):1517-24.

3. Kar A, Phadnis S, Dharmarajan S, Nakade J. Epidemiology \& social costs of haemophilia in India. Indian J Med Res 2014;140(1):19-31.

4. Konkle BA, Josephson NC, Nakaya Fletcher S. Editors. In: Pagon RA, Adam MP, Ardinger $\mathrm{HH}$, Wallace SE, Amemiya A, Bean LJH, Bird TD, Fong CT, Mefford HC, Smith RJH, Stephens K, editors. GeneReviews ${ }^{\circledR}$ [Internet]. Seattle (WA): University of Washington, Seattle; 1993-2016. 2000 Oct 02 [updated 2014 Jun 05].
5. Philipp C. The aging patient with hemophilia: complications, comorbidities, and management issues. Hematology $\mathrm{Am}$ Soc Hematol Educ Program 2010;2010:191-6. doi: 10.1182/ asheducation-2010.1.191.

6. Dharmarajan S, Phadnis S, Gund P, Kar A. Out-ofpocket 26. and catastrophic expenditure on treatment of haemophilia by Indian families. Haemophilia 2014;20:382-7

7. Balak DM, Gouw SC, Plug I, et al; Prenatal diagnosis for haemophilia: a nationwide survey among female carriers in the Netherlands. Haemophilia 2012;18(4):584-92.

8. Collins PW, Chalmers E, Hart DP, Liesner R, Rangarajan S, Talks K, Williams M, Hay CR; UK 
Haemophilia Centre Doctors. Diagnosis and treatment of factor VIII and IX inhibitors in congenital haemophilia: (4th edition). UK Haemophilia Centre Doctors Organization. Br J Haematol 2013;160(2):153-70.

9. Street AM, Ljung R, Lavery SA; Management of carriers and babies with haemophilia. Haemophilia 2008;14 Suppl3:181-7.
10. Keeling D, Tait C, Makris M; Guideline on the selection and use of therapeutic products to treat haemophilia. Haemophilia 2008;14(4):671-84. Epub 2008 Apr 4.

11. J R Korenberg, X N Chen, R Schipper, Z Sun, R Gonsky, S Gerwehr, N Carpenter, C Daumer, P Dignan, C Disteche, et al. Proc Natl Acad Sci 1994;91(11):4997-5001. 